\title{
FIRST REPORT AND MOLECULAR CHARACTERIZATION OF AN ISOLATE OF Papaya ringspot virus (PRSV-W) DETECTED IN PUMPKIN IN CUBA
}

\author{
PRIMEIRO RELATO E CARACTERIZAÇÃO MOLECULAR DE UM ISOLADO DE \\ Papaya ringspot virus (PRSV-W) DETECTADO EM PLANTA DE ABÓBORA \\ PROVENIENTE DE CUBA.
}

\author{
Douglas RODRÍGUEZ-MARTÍNEZ ${ }^{1}$; Antonia dos Reis FIGUEIRA ${ }^{\mathbf{1}}$; \\ Priscilla de Sousa Geraldino DUARTE ${ }^{1}$; Suellen Bárbara Ferreira GALVINO-COSTA ${ }^{\mathbf{1}}$; \\ Justo González OLMEDO ${ }^{2}$ \\ 1. Universidade Federal de Lavras- Departamento de Fitopatologia, Lavras, MG, Brazil. antonia@dfp.ufla.br; 2. Centro de Bioplantas, \\ Universidad de Ciego de Ávila, Carretera Morón Km.9, CP: 069450, Ciego de Ávila, Cuba.
}

\begin{abstract}
In this work, a virus isolate collected from pumpkin plants (Cucurbita pepo L.), showing severe symptoms of mosaic and leaf deformation, grown in Cuba, was analyzed using indicator plants, electron microscopy, and phylogenetic analysis. Plants of pumpkin, cv. Caserta, inoculated with this virus isolate showed mosaic, leaf distortion and blistering symptoms, whereas papaya plants were immune and did not show any symptoms. A transmission electron microscopic examination of leaf dip preparations made from infected pumpkin leaves revealed the presence of elongated and flexuous particles, approximately 780-800 x $12 \mathrm{~nm}$ in size. Genomic fragments containing the coat protein (CP) and HC-Pro genes, amplified by specific primers for Papaya ringspot virus, W strain (PRSV-W), showed amino acid identities of both genes higher than $94 \%$ when compared to other PRSV-W isolates from America. In the phylogenetic tree, this virus isolate has grouped with other virus isolates from America, Australia, and India and was more distant from the Asian isolates. Taken together, the analyses allow the conclusion that this virus isolate is a W strain of PRSV, detected for the first time in Cuba.
\end{abstract}

KEYWORDS: Molecular biology of virus. Virus TEM. Coat protein. HC-Pro. Virus phylogeny.

\section{INTRODUCTION}

To meet the increasing Cuban demand for food, the areas designated for agricultural crops, both in open fields and greenhouses, have been increased in recent years. Among these crops, cucurbits are important because of their good acceptance by the population. Several species of great economic interest are included in this group, with the most popular being cucumber (Cucumis sativus L.), watermelon (Citrullus vulgaris S.), melon (Cucumis melo L.) and summer and winter pumpkin (Cucurbita spp.). Among the pumpkin species belonging to the genus Cucurbita, the most cultivated in the world are Cucurbita pepo L., C. moschata L. and C. maxima L. (GONZAGA et al., 1999; LOY, 2004; PARIS and BROWN, 2005; VERONEZI and JORGE, 2012).

The commercial value of pumpkin fruits and seeds is profitable, and they are sold in several ways, such as sweets and snacks in markets and country fairs. Moreover, researchers have shown great interest in the use of pumpkin in medicine (CAILI et al., 2006; XANTHOPOULOU et al., 2009; OLOYEDE et al., 2012; PROCIDA et al., 2013) and in characterizing the nutritional compounds as well the possible use of pumpkin leaves in food (CHANDRIKA et al., 2010; OLOYEDE, 2012).

Similar to all annual crops, cucurbits can be affected by several diseases, including viral diseases, which are prominently known as being difficult to control. To date, more than 30 diseases caused by viruses and viroids infecting plants of the family Cucurbitaceae have been described (LOVISOLO, 1981; PROVVIDENTI, 1996; LECOQ et al., 1998). Among them, the most important are the following: Papaya ringspot virus (PRSV) - strain W (PRSV-W) and strain P (PRSV$\mathrm{P})$; Watermelon mosaic virus (WMV); Zucchini yellow mosaic virus (ZYMV); Zucchini lethal chlorosis virus (ZLCV); Cucumber mosaic virus (CMV) and Squash mosaic virus (SqMV) (YEH and GONSALVES, 1984; MOURA et al., 2001; MANGRAUTHIA et al. 2010; OLARTECASTILLO et al. 2011; PORTAL et al. 2006).

With different types of viruses that infect these plants, species of the Potyvirus genus are deemed of great importance because they are considered limiting factors in the major producing regions of the world, reducing both fruit quality and productivity (YEH et al., 1984; QUEMADA et al., 
1990; INOUE-NAGATA et al. 2007; OLARTECASTILLO et al. 2011). The prevalence of these viruses is due to the large number of aphids and virus host species in the Cucurbitaceae family (ATREYA et al. 1990; YEH et al. 1992).

One very important virus for squash is PRSV, which belongs to the Potyvirus genus, within the Potyviridae family. This virus has an elongated and flexuous particle of 760-800 x $12 \mathrm{~nm}$ and a single-stranded positive sense RNA (PURCIFULL et al., 1984; YEH et al., 1984). This virus is transmitted in a non-persistent manner by more than ten aphid species to different taxa of the Caricaceae and Cucurbitaceae families, hindering their control. The disease symptoms in pumpkin are characterized by an intense mosaic, a drastic reduction of the leaves and vegetative development and a reduction in production and fruit quality, resulting in losses of up to $100 \%$, depending on the age at which the plants are infected and also of the spread in the areas in which it occurs. The fruits may also present deformation and changes in color (PEREIRA et al., 2007; FREITAS and REZENDE, 2008, RAHMAN et al., 2010).

Thus far, there are few studies involving the characterization of PRSV in Cuba, with only the coat protein $(\mathrm{CP})$ genes of two PRSV-P isolates being partially sequenced and analyzed (Oliveira et al. 2000). In this study, a W strain of PRSV collected in a growing area located in the province of Pinar del Rio, Cuba, was identified and characterized for the first time from leaf samples of pumpkin plants showing mosaic and leaf distortion. In addition to the study of the symptoms induced by the virus in pumpkin plants $\mathrm{cv}$. Caserta, the $\mathrm{CP}$ and HCPro genes were sequenced and analyzed.

\section{MATERIAL AND METHODS}

A sample of pumpkin leaves was collected in the city Los Palacios in Pinar del Río, a province where the plants showed symptoms of severe mosaic, leaf distortion and little vegetative growth. The leaves were collected and dried for transport to Laboratory. After serological diagnosis, the virus isolate was named Cuba-PR and inoculated in pumpkin cv. Caserta in special growth chambers to avoid environmental escape. The inoculum was stored dry at $-20{ }^{\circ} \mathrm{C}$ and fresh at $-80{ }^{\circ} \mathrm{C}$.

\section{Symptom survey}

The inoculum was obtained by grinding the infected leaves in a porcelain mortar with $0.01 \mathrm{M}$ phosphate buffer, $\mathrm{pH} 7.0$, plus sodium sulfite at the same molarity $(1: 10 \mathrm{w} / \mathrm{v})$. The virus was mechanically inoculated using carborundum (CSi) on the first pair of leaves showing approximately $2 / 3$ of expansion. Six plants from each of the following were used: pumpkin cv. Caserta (C. pepo), papaya cv. Sunrise Solo (Carica papaya L.), Chenopodium amaranticolor Coste and Reyn. and C. quinoa Willd. These plants were obtained by sowing seeds in pots (capacity of $2 \mathrm{~kg}$ ) containing the appropriate substrate. The plants were maintained in a special growth chamber during the experiment and inspected daily for the evaluation of the typical viral symptoms.

\section{Transmission electron microscopy}

The experiment was performed at the Laboratory of Electron Microscopy and Ultrastructural Analysis, Department of Plant Pathology, Federal University of Lavras. The leaf dip technique for the observation of viral particles used pumpkin leaves collected from plants with symptoms of mosaic and leaf distortion; healthy leaves were used as the negative control. The plant tissue was cut into small fragments in the presence of potassium phosphate buffer $0.01 \mathrm{M}, \mathrm{pH} 7.0$, plus sodium sulfite at the same concentration. The extract obtained was applied to a 300-mesh copper screen coated with Formvar $(0.25$ g Formvar +50 $\mathrm{ml}$ chloroform) for 5 minutes. Uranyl acetate (2\%) was applied for 3 minutes for contrast. The observations were made after 72 hours using a Zeiss EM 109 transmission electron microscope at 12.000 $\mathrm{x}$ of magnification.

\section{RNA extraction, RT-PCR, purification and sequencing}

Total RNA was extracted from symptomatic leaves using the Trizol method and the RT-PCR reactions were performed using two pairs of primer designed based on sequences from GenBank (http://www.ncbi.nlm.nih.gov/genbank/), as follows: to amplify the CP gene - PRSV9016-F, 5' CTTGARCARGCTCCATTC 3', and PRSV10253R, 5' CTAAAAGCACGGAGG 3' and to amplify the HC-Pro gene - PRSV1593-F, 5' TYAARCCRAARTTYGCYG 3', and PRSV3079R, 5' CATTTCACTATCGAGYGG 3'. The enzymes employed were M-MLV Reverse Transcriptase and GoTaq $^{\circledR}$ Flexi DNA Polymerase (both from Promega, Corp. Madison, WI, USA). The PCR cycle was as follows: initial denaturation at $95{ }^{\circ} \mathrm{C}$ for 2 minutes, followed by 35 cycles of $95{ }^{\circ} \mathrm{C}$ for 45 seconds, $50{ }^{\circ} \mathrm{C}$ (HC-Pro) or $42^{\circ} \mathrm{C}(\mathrm{CP})$ for 1 minute and $72{ }^{\circ} \mathrm{C}$ for 1.5 minutes (HC-Pro) or 1 minute (CP) and a final extension at $72{ }^{\circ} \mathrm{C}$ for 5 minutes. The product was analyzed by electrophoresis on a 
First report...

$0.7 \%$ agarose gel and purified using the purification kit from Qiagen following the manufacturer's recommendations (Qiagen, São Paulo, SP, Brazil). The fragment was sequenced by Genewiz (South Plainfield, NJ, USA).

\section{Alignment and sequence analysis}

The contigs based on the sequences obtained were constructed using the program DNA Baser Sequence Assembler v. 2 (www.dnabaser.com) and analyzed by BLAST

\section{RODRÍGUEZ-MARTÍNEZ, D. et al}

using at NCBI (http://www.ncbi.nlm.nih.gov/). The multiple alignments of the nucleotide and amino acid sequences of the studied virus isolate with the other virus isolates available in GenBank (Table 1) were performed using the ClustalW program included in MEGA5 (TAMURA et al. 2011). The genetic distances and phylogenetic trees by the Neighbor-Joining method were generated using the program MEGA5 (TAMURA et al. 2011), with bootstrapping and 2.000 replicates.

Table 1. Papaya ringspot virus sequences available in GenBank, used for comparison

\begin{tabular}{|c|c|c|c|c|c|}
\hline Country & Isolate & Strain & State/Province & $\begin{array}{l}\text { Access in } \\
\text { GenBank }\end{array}$ & Gene \\
\hline Cuba & IBP-SDo & $P$ & Villa Clara & AY841757 & $C P$ \\
\hline Cuba & Boyeros & $P$ & Havana & $D Q 089482$ & $C P$ \\
\hline Brazil & $P R S V-W-1$ & $W$ & Distrito Federal & $D Q 374153$ & $\mathrm{CP}$ and $\mathrm{HC}$-Pro \\
\hline Brazil & $P R S V-W-2$ & $W$ & São Paulo & AF530088 & $C P$ \\
\hline Brazil & PRSV-W-3 & $W$ & São Paulo & AY094986 & $C P$ \\
\hline Brazil & $P R S V-W-C$ & $W$ & São Paulo & $D Q 374152$ & $\mathrm{CP}$ and $\mathrm{HC}$-Pro \\
\hline$U S A$ & $\mathrm{~T} 14 \mathrm{~b}$ & $W$ & Oklahoma & $J N 132470$ & $C P$ \\
\hline USA & $T 2$ & $W$ & Oklahoma & $J N 132456$ & $C P$ \\
\hline USA & B9 & $W$ & Oklahoma & JN132432 & $C P$ \\
\hline$U S A$ & $\mathrm{Fl}$ & $W$ & Florida & D00594 & $C P$ \\
\hline Taiwan & $\mathrm{CI}$ & $W$ & Chiayi & AY027810 & $C P$ \\
\hline Taiwan & PT & $W$ & Pintung & AY027811 & $C P$ \\
\hline Thailand & PRSVth & $W$ & $N K$ & AY010722 & $\mathrm{CP}$ and $\mathrm{HC}$-Pro \\
\hline China & Ch99/113 & $W$ & Henan & $D Q 868880$ & $C P$ \\
\hline China & $\mathrm{BN}$ & $W$ & $N K$ & $D Q 449533$ & $C P$ \\
\hline Índia & IND & $W$ & Delhi & EU475877 & $\mathrm{CP}$ and $\mathrm{HC}$-Pro \\
\hline Índia & New Delhi & $W$ & Nova Delhi & EU556733 & HC-Pro \\
\hline Israel & Israel & $W$ & $N K$ & $J F 737858$ & HC-Pro \\
\hline Australia & GAT & $W$ & Gatton & U14739 & $C P$ \\
\hline Australia & $N T$ & $W$ & Northern Region & U14744 & $C P$ \\
\hline
\end{tabular}

NK not known, CP coat protein, HC-Pro helper component proteinase

\section{RESULTS AND DISCUSSION}

The first mild mosaic symptoms appeared in the pumpkin cv. Caserta plants at 16 days after the inoculation of the Cuba-PR isolate. During plant development, the symptoms became stronger in the young leaves, causing leaf reduction and malformation (Figure 1A and 1C), as observed by other authors in cucurbit plants infected with PRSVW (PURCIFULL and HIEBERT , 1979 ; YEH et al.
1984; PEREIRA et al., 2007; FREITAS and REZENDE, 2008). In contrast, even after five repetitions of mechanical inoculation, papaya plants did not become infected. Attempts to recover the virus from the papaya plant by the mechanical inoculation of leaf extracts were unsuccessful. Therefore, as it was PCR positive for PRSV, this virus isolate was characterized as strain $\mathrm{W}$, which is only able to infect cucurbits (PURCIFULL et al. 1984). 


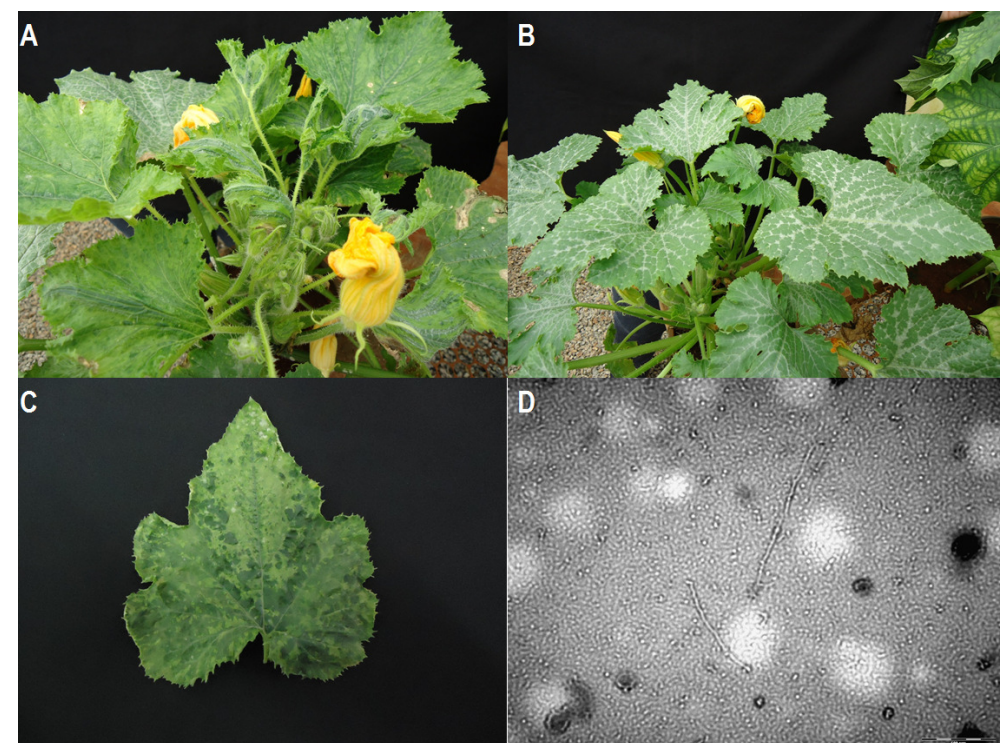

Figure 1. A and C: symptoms of mosaic, blistering and leaf distortion in pumpkin plants cv. Caserta, mechanically inoculated with Cuba-PR isolate; B: health pumpkin plants cv. Caserta; D: transmission electron micrograph of Cuba-PR particles obtained by leaf dip method.

Using the leaf dip method, elongated and flexuous particles of approximately 760-800 x 12 $\mathrm{nm}$ were observed in the leaf extract of infected plants (Fig. 1 D), which is similar to the PRSV-W particles already described (PURCIFULL et al. 1984; YEH et al., 1984).

With the primers corresponding to position 9,016-10,253 of the PRSV genome a fragment of 1238 bp (Fig. 2 A) was obtained (GenBank Accession number KC768854). This region contains the 927-bp CP gene, which is located at position 9,284 to 10,210 of the genome of the PRSV-W-C isolate sequenced by Inoue-Nagata et al. (2007) (GenBank DQ374152 access). For the identity and phylogeny analyses, only a portion of the $\mathrm{CP}$ gene and an 837-bp fragment located at position 9,284 to 10,120 PRSV-W-C was used to enable the comparison with other sequences available in GenBank, which are mostly partial sequences.

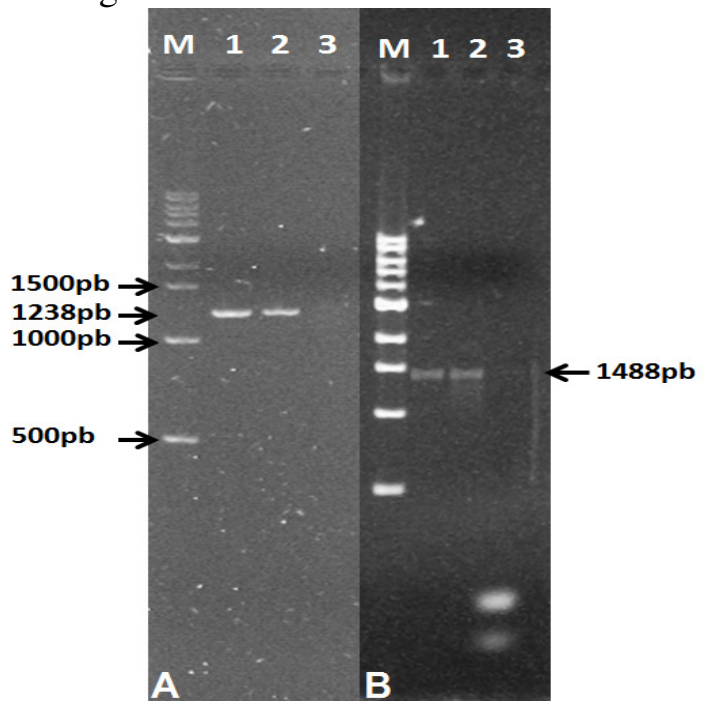

Figure 2. Analysis of the RT-PCR products on a $0.7 \%$ agarose gel. A: M- $1 \mathrm{~kb}$ Ladder, line 1 and 2- CP gene and line 3- negative control ; B: M- 1 kb Ladder, line 1 and 2- HC-Pro gene and line 3-negative control.

The Cuba-PR fragment (837 nucleotides) was compared to $18 \mathrm{CP}$ sequences available in GenBank (Table 1) and was found to be similar to the following 10 virus isolates: AY841757 from
Cuba; JN132470, JN132456, JN132432 and D00594 from The United States; DQ374152 from Brazil; AY027811 from Taiwan; DQ449533 from China and U14739 and U14744 from Australia. 
Moreover, the comparison made with the PRSVth (Thai) and IBP-SDo (Cuban) isolates showed that they were three and six nucleotides shorter than Cuba-PR, respectively. The other Brazilian, Chinese, and Thai isolates included in this analysis were six nucleotides longer than Cuba-PR.

These differences in the sizes of the $\mathrm{CP}$ fragments are due to the insertion of two amino acids in the Brazilian isolates PRSV-W-1, PRSV$\mathrm{W}-2$, and PRSV-W-3, as previously reported by Inoue Nagata et al. (2007), and a deletion of two amino acids in the Cuban isolate IBP-SDo (PORTAL et al. 2006). These insertions and deletions in the $\mathrm{N}$-terminal $\mathrm{CP}$ region suggest that this region is highly variable and that the gene is subject to nucleotide insertions and deletions (LIMA et al. 2002).

It is important to mention that in Cuba-PR, and in the virus isolates from GenBank, there is the presence of EK repetitive regions and the conserved domains WCIEN and QMKAAA (Fig. 3), which have been reported by several authors as having functions related to virus transmission by aphids (ATREYA et al. 1990; SHUKLA and WARD 1989; SILVA-ROSALES et al. 2000).

Cuba-PR ..EKLKEKEKQKEKEKEKQKEKEKD...MVWCIENGT...HMQMKAAALRN... Boyeros-Cuba ..EKLKEKEKQKEKEKEKQKEKEKD...MVWCIENGT...HMQMKAAALRN... IBP-SDo-Cuba ...-NEKLKEKEKQKEKEKQKEKEKD...MVWCIENGT...HMQMKAAALRN... PRSV-W-C-Brazil ..EKRKEKGNQKEKEEEKQKEKEKD...MVWCIENGT...HMQMKAAALRN... PRSV-W-3-Brazil ..DKLKEKEKQKEKEKDKQKEKEKG...MVWCIENGT...HMQMKAAALRN... PRSV-W-2-Brazil ..DKLKEKEKQKEKEKDKQKEKEKG...MVWCIENGT...HMQMKAAALRN... PRSV-W-1-Brazil ..DKLKEKEKQKEKEKDKQKEKEKG...MVWCIENGT...HMQMKAAALRN...

T14b-USA ..EKLKEKEKQKEKEKEKQKEKEKD...MVWCIENGT...HMQMKAAALRN... T2-USA ..EKLKEKEKQKEKEKEKQKEKEKD...MVWCIENGT...HMQMKAAALRN... B9-USA ..EKLKEKEKQKEKEKEKQKEKEKD...MVWCIENGT...HMQMKAAALRN... NT-Australia ..EKLKEKEKQKEKEKEKQKEKEKD...MVWCIENGT...HMQMKAAALRN... FL-USA ..EKFKEKEKQKEKEKEKQKEKEKD...MVWCIENGT...HMQMKAAALRN... Gatton-Australia ..EKLKEKEKQKEKEKEKQKEKEKD...VVWCIENGT...HMQMKAAALRN... CI-Taiwan ..LKEKEKEKQKEKEKDEQKDKDND..MVWCIENGT...HMQMKAAALRN... Ch99/113-China ..LKEKEKQKEKEKEKEKQKDEDND...MVWCIENGT...HMQMKAAALRN... PRSVth-Thailand ..FKEKEKQKE---EKDKQKDKNND...MVWCIENGT...HMQMKAAALRN... PT-Taiwan ..EKLKEKEKQKEKEKDKQKDKDND...MVWCIENGT...HMQMKAAALRP... BN-China ..EKLKEKEKLKEKEKEKQKEKDND...MVWCIENGT...HMQMKAAALRN... IND-India ..DKLKEKEKSKEKEKEKQKEKEKD...MVWCIENGT...HMQMKAAALQN...

Figure 3. EK repetitive regions, WCIEN and QMKAAA conserved domains on PRSV CP protein.

Comparing the Cuba-PR isolate with two other virus isolates available in GenBank, we observed that this region is identical to BoyerosCuba (a PRSV-P isolate) but different from IBPSDo-Cuba, which lacks one amino acid in the first position, has an $\mathrm{L}$ replacing an $\mathrm{E}$ in the fifth position and has an E replacing a Q in the ninth position.

The multiple alignment of the CP nucleotide sequences showed that the identity of the Cuba-PR isolate with the virus isolates used for comparison ranged from $89.1 \%$ (the PRSVth isolate from Thailand) and 97.6\% (PRSV-W-3 from Brazil) (data not shown). However, the amino acid identity ranged from 93.9\% (IBPSDo from Cuba) and 98.2\% (the three U.S. isolates mentioned above). Therefore, the Cuba-PR isolate showed high identities with the virus isolates from America, which is geographically closer, than with those from Asia for which the identity was lower. An exception was observed with the IBP-SDo Cuban isolate, which, though not showing the lowest nucleotide identity, presented the lowest amino acid identity; this result indicated that the substitutions that occurred were non-synonymous, resulting in changes in amino acids. However, the observations could be because the Cuban isolates, unlike the others, are of the PRSV-P type.

The results of this study are similar to those found by Inoue-Nagata et al. (2007), who reported the nucleotide sequence identities of the $\mathrm{CP}$ region among the American and Asian isolates between $90 \%$ and $95 \%$. Abdalla and Ali (2012) reported higher values for both the nucleotide $(95.2 \%-100 \%)$ and amino acid sequences (97.1\%-100\%). However, these higher values are most likely because Abdalla and Ali (2012) only compared PRSV-W isolates from different areas in Oklahoma (USA). 
The phylogenetic trees based on the nucleotide and amino acid sequences are shown in Fig. 4 (A and B, respectively). The tree based on the nucleotide sequences showed two main clusters grouping the PRSV isolates. The first and larger were divided in two subgroups, one with the American and Australian isolates, and another with the sole Indian isolate, showing its uniqueness when compared to the first subgroup. The second and smaller cluster grouped with the Asian isolates. It was observed that the Cuban PRSV-P isolates were closer to PRSV-W from The United States and Australia. However, the Cuba-PR isolate grouped with the Brazilian PRSV-W isolates, most likely because they belong to the $\mathrm{W}$ strain, unlike the other two Cuban strains that belong to the $\mathrm{P}$ strain. Another possibility is that these isolates could have been originated from different geographic regions.
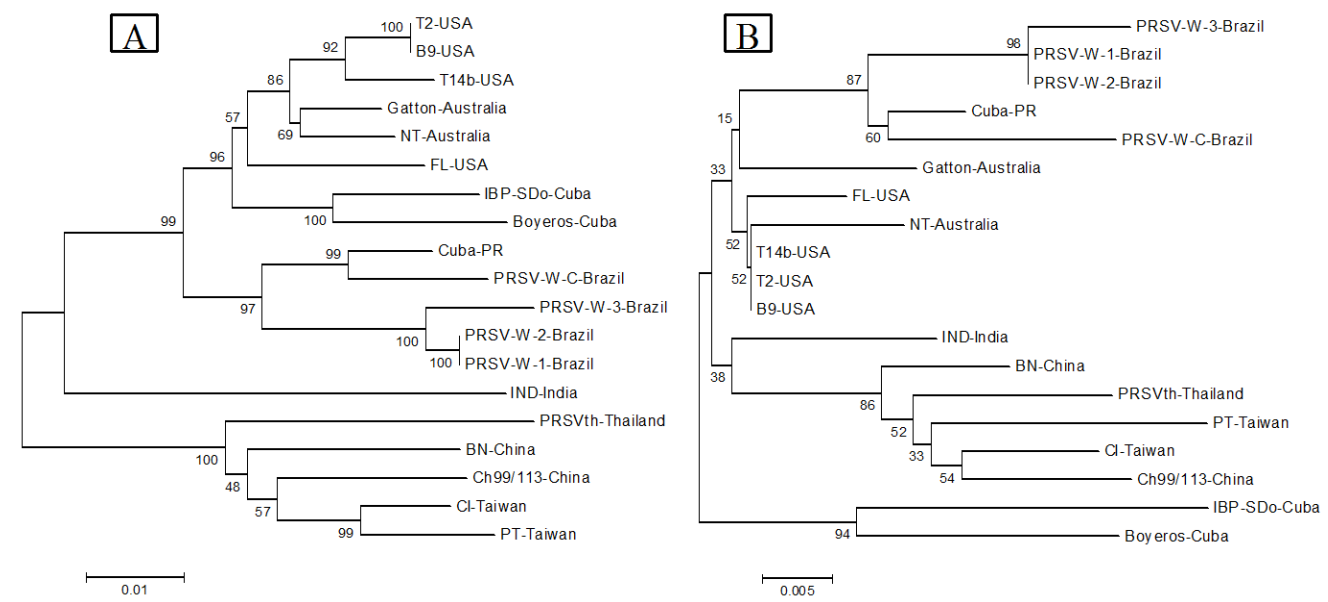

Figure 4. Phylogenetic trees based on the nucleotide (A) and amino acids (B) sequences of the coat protein gene of Cuba-PR isolate and the remaining isolates available in GenBank. Bootstrap values were obtained by MEGA5 program, using Neighbor Joining with 2.000 replicates.

The tree based on the amino acid sequences also showed two clusters, but their composition was slightly different. In this tree, the first cluster also had two subgroups: one containing the isolates from America, Australia, and the Cuba-PR isolate closer to the Brazilian isolates and the other containing the virus isolates from India and Asia. The second and smaller cluster grouped the two PRSV-P isolates from Cuba, which were clustered separately from the rest.

Phylogenetic distance among the American and Asian isolates, as observed in the tree based on the nucleotide sequence, was also reported by Inoue-Nagata et al. (2007) and Abdalla and Ali (2012), reporting genetic similarity among the American and Australian isolates. Several other authors have found the same genetic similarity between the Asian, American and Australian isolates (FERNÁNDEZ-RODRÍGUEZ et al. 2008; LIMA et al. 2002; LU et al. 2008). These data confirm a possible Indian origin of PRSV, with a posterior spread to the Americas and Australia (OLARTE-CASTILLO et al. 2011).

Using specific primers for the HC-Pro gene, a 1,488-bp fragment was amplified and sequenced (GenBank accession number KC768855; Fig. 2B) and found to correspond to the genome position
1.727 to 3.060 of the PRSV-W-C isolate DQ374152 (INOUE-NAGATA et al. 2007). The sequence of this fragment was analyzed and compared to the six sequences of PRSV-W available in GenBank (Table 1). The identity between the nucleotide sequences of the Cuba-PR and remaining strains (data not shown) ranged from $70.6 \%$ to $98 \%$, and the highest value was observed for the Brazilian isolate PRSV-W-C. Again, smaller identities were observed when it was compared to the Asian isolates, most likely due to the great geographical distance.

When the amino acid sequences were analyzed, it was observed that the isolate Cuba-PR, along with the others available in GenBank, showed the conserved KITC and PTK domains (Fig. 5) that, according to some reports, are involved in interactions between the virion and the structure of the aphid stylet during non-persistent transmission (HUET et al., 1994; YAP et al. 2009). As observed for $\mathrm{CP}$, the identities among the amino acid sequences (data not shown) were higher than the identities of the nucleotides, with values ranging between $96.8 \%$ and $99.1 \%$. The highest identity was observed for the PRSV-W-C isolate from Brazil, and the lowest value occurred with the virus isolates from India and Israel. 


\section{IND-India ...FRCHKITCNTCMSR...LKTPTKNHI \\ NewDelhi-India ...FRCHKITCNTCMSR...LKTPTKNHI \\ Israel ...FPCHKITCNTCMSK...LKTPTKNHI \\ Cuba-PR ...FPCHKITCNTCMSK...LKTPTKNHI \\ PRSV-W-C-Brazil ...FPCHKITCNTCMSK...LKTPTKNHI \\ PRSV-W-1-Brazil ...FPCHKITCNTCMSE...LKTPTKNHI \\ PRSVth-Thailand ...FPCHKITCNTCMNK...LKTPTKNHI}

Figure 5. KITC and PTK conserved domains on PRSV HC-Pro gene.

In the phylogenetic trees based on both nucleotide (Fig. 6A) and amino acid sequences (Fig. 6B), the Cuba-PR isolate grouped with two Brazilian isolates (PRSV-W-C and PRSV-W-1). In the tree based on the nucleotide sequences, the virus isolates grouped into two clusters, and the virus isolates from India were closest to the virus isolates from America, with the virus isolates from Israel being separated into the second cluster. In the tree based on the amino acid sequences, the virus isolates from India were in a cluster far from the American isolates, in the same cluster with the virus isolate from Israel but in a different subgroup.

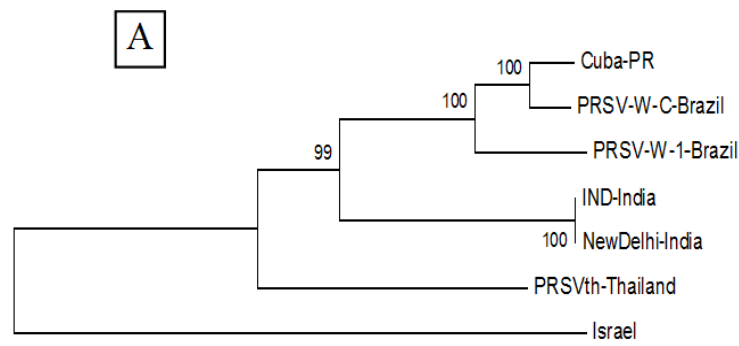

0.02

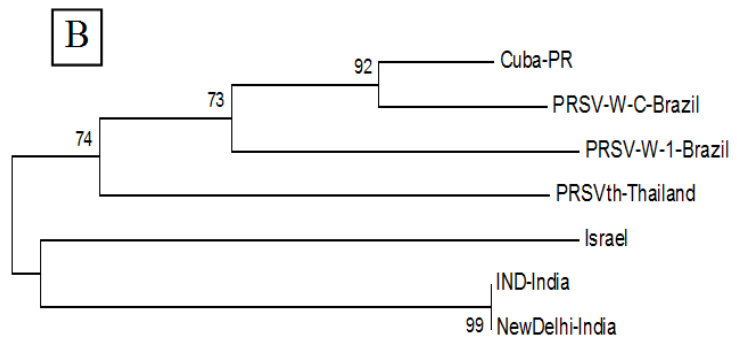

0.005

Figure 6. Phylogenetic trees based on the nucleotide (A) and amino acids (B) sequences of the HC-Pro gene from Cuba-PR isolate and the remaining isolates available in GenBank. Bootstrap values obtained by MEGA5 program, using Neighbor Joining with 2.000 replicates.

In the phylogenetic trees based on the sequences of both HC-Pro and $\mathrm{CP}$, the virus isolates were clustered according to their geographic region, with the Cuba-PR isolate being closer to the virus isolates from America and India. The trees based on $\mathrm{CP}$ showed the American isolates closely grouped with the virus isolates from Australia, which was not observed in the trees based on HC-Pro because there was no sequence from this country available in GenBank. These regional groupings based on the HC-Pro gene have been reported by other authors (INOUE-NAGATA et al. 2007; LU et al. 2008; OLARTE-CASTILLO et al. 2011). A curious fact is that, for both genes, the virus isolates from India were grouped closer to the American isolates only in the trees based on nucleotide sequences.

The nucleotide sequences were more conserved for the CP gene than for HC-Pro, whereas the opposite was observed for the amino acid sequences. Therefore, the HC-Pro protein is more conserved than $\mathrm{CP}$, most likely due to their respective functions in virus-plant interactions. It would be interesting to obtain additional HC-Pro sequences to perform genetic analyses, but, unfortunately, there were few sequences available in GenBank.

The results obtained in this study help in the understanding of the genetic diversity of PRSV-W cucurbit infection and suggest the importance of including this virus in surveillance programs and pest management in crops of pumpkin and other cucurbits in Cuba; genetic breeding programs for resistance should also be implemented. Such efforts certainly will contribute to increase cucurbit yields, thus meeting the food demand of this country.

\section{ACKNOWLEDGMENTS}

Thanks To Student Program AgreementGraduate (PEC-PG) and the Coordination of Improvement of Higher Education Personnel (CAPES) for the scholarship and funding of this project, as the National Council for Scientific and Technological Development (CNPq) and the 
Foundation for Research Support of the State of Minas Gerais (FAPEMIG) for their support in funding reagents and resources for the project.

RESUMO: Neste trabalho um isolado viral coletado em planta de abóbora (Cucurbita pepo L), apresentando sintomas severos de mosaico e deformação foliar, proveniente de uma lavoura localizada em Cuba, foi analisado utilizando plantas indicadoras, microscopia eletrônica de transmissão e análise filogenética. Plantas de abóbora cv. Caserta, inoculadas com este isolado do vírus mostrou mosaico, distorção foliar e bolhas, enquanto que as plantas de mamão foram imunes e não apresentaram sintoma. Exame ao microscópio eletrônico de tranmissão de telas preparadas com a técnica leaf dip, empregando o extrato de folhas de abóbora infectadas revelou a presença de partículas alongadas e flexuosas, medindo cerca de 780-800 × $12 \mathrm{~nm}$. A análise de fragmentos genômicos contendo os genes da proteína capsidial (CP) e HC-Pro, amplificados por primers específicos para Papaya ringspot virus, estirpe W (PRSV -W), mostrou identidades de aminoácidos superiores a $94 \%$ quando ambos os genes foram comparados a outros isolados americanos de PRSV -W. Na árvore filogenética, este isolado estudado se agrupou com os isolados de PRSV-W da América, Austrália e Índia, ficando mais distante dos isolados asiáticos. Tomadas em conjunto, as análises permitem concluir que este isolado viral pertence à estirpe W do PRSV, detectada pela primeira vez em Cuba.

PALAVRAS CHAVE: Biologia molecular de vírus. MET de vírus. Capa proteica. HC-Pro. Filogenia de vírus.

\section{REFERENCES}

ABDALLA, O. A., ALI, A. (2012). Genetic diversity in the 3'-terminal region of Papaya ringspot virus (PRSVW) isolates from watermelon in Oklahoma. Arch. Virol, New York, v. 157. n. 3, p. 405-412, 2012. http://dx.doi.org/10.1007/s00705-011-1184-8

ATREYA, C. D., RACCAH, B., AND PIRONE, T. P. A point mutation in the coat protein abolishes aphid transmissibility of a potyvirus. Virology, New York, v. 178. n. 1, p. 161-165, 1990. http://dx.doi.org/10.1016/0042-6822(90)90389-9

CAILI, F. U, HUAN, S., QUANHONG, L. A Review on Pharmacological Activities and Utilization Technologies of Pumpkin. Plant Foods for Human Nutrition, New York, v. 61, n. 2, p. 73-80, 2006. http://dx.doi.org/10.1007/s11130-006-0016-6

FERNÁNDEZ-RODRÍGUEZ, T., RUBIO, L., CARBALLO, O., AND MARYS, E. Genetic variation of Papaya ringspot virus in Venezuela. Archives of Virology, New York, v. 153, n. 2, p. 343-349, 2008. http://dx.doi.org/10.1007/s00705-007-1091-1

FREITAS, D. M. S. REZENDE, J. A. M. Protection between strains of Papaya ringspot virus - type W in zucchini squash involves competition for viral replication sites. Sci. Agric., Piracicaba, v. 65, n. 2., p. 183-189, 2008.

GONZAGA V, FONSECA JNL, BUSTAMANTE PG, TENENTE RCV. Cucurbits germplasm exchange. Hortic. Bras., Brasília, v. 17, n. S, p. 06-09, 1999.

HUET, H., GAL-ON, A., MEIR, E., LECOQ, H., RACCAH, B. Mutations in the helper component protease gene of zucchini yellow mosaic virus affect its ability to mediate aphid transmissibility. Journal of General Virology, London, v. 75, n. 6, p. 1407-1414, 1994. http://dx.doi.org/10.1099/0022-1317-75-6-1407

INOUE-NAGATA, A. K., FRANCO, C. M., MARTIN, D. P., REZENDE, J. A. M., FERREIRA, G.B., DUTRA, L. S., AND NAGATA, T. Genome analysis of a severe and a mild isolate of Papaya ringspot virustype W found in Brazil. Virus Genes, Norwell, Mass., v. 35, n. 1, p. 119-127, 2007. http://dx.doi.org/10.1007/s11262-006-0032-5 
LECOQ, H.; WILSER, G.; PITRAT, M. Cucurbit viruses: the classics and the emerging. In: McCreight J. D. (Ed.). Evaluation and enhancement of cucurbit germplasm. American Society of Horticultural Sciences. Alexandria, 1998. p. 126-142.

LIMA, R. C. A., SOUZA, M. T., PIO-RIBEIRO, G., LIMA, J. A. A. Sequences of the coat protein gene from Brazilian isolates of Papaya ringspot virus. Fitopatologia Brasileira, Brasília, v. 27, n. 2, p. 174-180, 2002. http://dx.doi.org/10.1590/S0100-41582002000200009

LOVISOLO, O. Virus and viroid diseases of cucurbits. Acta Hort. (IHS), The Hague, NL, v. 88, p. 33 - 82, 1981.

LOY J. Morpho-Physiological Aspects of Productivity and Quality in Squash and Pumpkins (Cucurbita spp.) Crit. Rev. Plant Sci., Boca Raton, v. 23, n. 4, p. 337-363. 2004.

LU, Y. W., SHEN, W. T., ZHOU, P., TANG, Q. J., NIU, Y. M., PENG, M., AND XIONG, Z. Complete genomic sequence of a Papaya ringspot virus isolate from Hainan Island, China. Arch. Virol., New York, v. 153, n. 5, p. 991-993, 2008.

MANGRAUTHIA, S. K., SINGH, P., AND PRAVEEN, S. (2010). Genomics of Helper Component Proteinase Reveals Effective Strategy for Papaya ringspot virus Resistance. Molecular Biotechnology, Totowa, v. 44, n. 1, p. 22-29, 2010. http://dx.doi.org/10.1007/s12033-009-9205-5

MOURA, M. C. C. L., LIMA, J. A. A., OLIVEIRA, V. B., AND GONÇALVES, M. F. B. (2001). Serological identification of virus species infecting cucurbits in producing areas of the State of Maranhão, Brazil.

Fitopatologia Brasileira, Brasília, v. 26, n. 1, p. 90-92. http://dx.doi.org/10.1590/S0100-41582001000100016

OLARTE CASTILLO, X. A., FERMIN, G., TABIMA, J., ROJAS, Y., TENNANT, P. F., FUCHS, M., SIERRA, F., BERNAL, A. J., AND RESTREPO, S. Phylogeography and molecular epidemiology of Papaya ringspot virus. Virus Research, Amsterdan, v. 169, n. 2, p. 132-149, 2011.

OLIVEIRA, V. B., LIMA, J. A. A., VALE, C. C., AND PAIVA, W. O. Biological and serological characterization of potyvirus isolates obtained from cucurbit in the Northeast of Brazil. Fitopatologia Brasileira, Brasília, v. 25, n. 4, p. 628-636, 2000.

OLOYEDE, F. M. Growth, yield and antioxidant profile of pumpkin (Cucurbita pepo L.) leafy vegetable as affected by NPK compound fertilizer. J. Soil Sci. Plant Nutr., Chile, v. 12, n. 3, p. 379-388. 2012.

OLOYEDE, F. M., AGBAJE, G. O., OBUOTOR, E. M., OBISESAN, I. O. Nutritional and antioxidant profiles of pumpkin (Cucurbita pepo Linn.) immature and mature fruits as influenced by NPK fertilizer. Food Chemistry, London, v. 135, n. 2, p. 460-463, 2012. http://dx.doi.org/10.1016/j.foodchem.2012.04.124

PARIS, H. S., BROWN, R. N. The genes of Pumpkin and Squash. HortScience, Alexandria VA, v. 40, n. 6, p. 1630-1630, 2005.

PEREIRA, M. J. Z., SUSSEL, A. A. B., SILVA, R. F., KUHN, O. J., DOMINGUES, F., REZENDE, J. A. M. Damages in the zucchini squash production caused by Papaya ringspot virus - type $\mathrm{W}$ e Zucchini yellow mosaic virus. Summa Phytopathologica, Jaguariuma, v. 33, n. 2, p. 192-194, 2007.

PORTAL, O., CABRERA, D., SÁNCHEZ, A., DARÍAS, A. L., GONZÁLEZ, J. E, AND GÓMEZ, R. Molecular characterization of two Cuban isolates of Papaya ringspot virus by means of coat proteins analysis. Commun. Agric. Appl. Biol. Sci., Belgium, v. 71, n. 3, 1203-1205, 2006.

PROCIDA, G., STANCHER, B., CATENIA, F., ZACCHIGNAA, M. Chemical composition and functional characterization of commercial pumpkin seed oil. J. Sci. Food Agric., London, v. 93, n. 5, p. 1035-1041, 2013. 
PROVVIDENTI, R. (1996). Diseases caused by viruses. In: ZITTER, HOPKINS, THOMAS (Eds.), Compendium of Cucurbit Diseases. St. Paul, MN, USA. American Phytopathological Society, 1996. p. 25-45.

PURCIFULL, D. E., AND E. HIEBERT. Serological distinction of watermelon mosaic virus isolates. Phytopathology, Saint Paul, v. 69, n. 2, p. 112-116.1979

PURCIFULL, D. E., EDWARDSON, J. R, HIEBERT, E., AND GONSALVES, D. (1984). Papaya ringspot virus. CMI/AAB. Description of plant viruses, (online publication), n. 292. 8p.

QUEMADA,H., L'HOSTIS, B., GONSALVES, D., REARDON, I. M., HEINRIKSON, R., HIEBERT, E. L., SIEU , L. C., SLIGHTOM, J. L. The nucleotide sequences of the 3'-terminal regions of papaya ringspot virus strains W and P. Journal of General Virology, London, v. 71, n. 1, p. 203-210, 1990.

http://dx.doi.org/10.1099/0022-1317-71-1-203

RAHMAN, M. F., AKANDA, M. A, SARKAR, M. Z. A. Effect of mild strain on severity of PRSV-W infection. Bangladesh J. Agric. Res. Bangladesh, v. 35, n. 2, p. 279-285, 2010.

http://dx.doi.org/10.3329/bjar.v35i2.5891

SHUKLA, D. D.; WARD, C. W. Structure of potyvirus coat proteins and its application in the taxonomy of the potyvirus group. Advances in Virus Research, San Diego, v. 36, p. 273-314, 1989.

http://dx.doi.org/10.1016/S0065-3527(08)60588-6

SILVA-ROSALES, L., BECERRA-LEOR, N., RUIZ-CASTRO, S., TELIZ-ORTIZ, D., AND NOA-

CARRAZANA, J. C. Coat protein sequence comparisons of three Mexican isolates of Papaya ringspot virus with other geographical isolates reveal a close relationship to American and Australian isolates. Arch. Virol., New York, v. 145, n. 4, p. 835-843, 2000.

TAMURA, K.; PETERSON D.; PETERSON, N.; STECHER, G.; NEI, M.; KUMAR, S. MEGA5: Molecular Evolutionary Genetics Analysis using Maximum Likelihood, Evolutionary Distance, and Maximum Parsimony Methods. Molecular Biology and Evolution, Chicago, v. 28, n. 10, p. 2731-2739, 2011.

http://dx.doi.org/10.1093/molbev/msr121

VERONEZI, C. M., JORGE, N. Bioactive Compounds in Lipid Fractions of Pumpkin (Cucurbita sp) Seeds for Use in Food. Journal of Food Science, Chicago, v. 77, n. 6, p. C653- C657, 2012. http://dx.doi.org/10.1111/j.1750-3841.2012.02736.x

XANTHOPOULOU, M. N., NOMIKOS, T. FRAGOPOULOU, E.; ANTONOPOULOU, S. Antioxidant and lipoxygenase inhibitory activities of pumpkin seed extracts. Food. Res. Int., Barking, v. 42, n. 5-6, p. 641-646, 2009.

YAP, Y. K., DUANGJIT, J., AND PANYIM, S. N-Terminal of Papaya ringspot virus type-W (PRSV-W) helper component proteinase (HC-Pro) is essential for PRSV systemic infection in zucchini. Virus Genes, Norwell, v. 38, n. 3, p. 461-467, 2009. http://dx.doi.org/10.1007/s11262-009-0348-z

YEH, S. D., JAN, F. J., CHIANG, C. H., DOONG, T. J., CHEN, M. C., CHUNG, P. H., BAU, H. J. Complete nucleotide sequence and genetic organization of Papaya ringspot virus RNA. J. Gen. Virol., London, v. 73, n. 10, p. 2531-2541, 1992.

YEH, S.-D., GONSALVES, D. Evaluation of induced mutants of papaya ringspot virus for control by crossprotection. Phytopathology, St. Paul, v. 74, n. 9, p. 1086-1091, 1984.

YEH, S. D., GONSALVES, D., PROVVIDENTI, R. Comparative studies on host range and serology of Papaya ringspot virus and watermelon mosaic virus I. Phytopathology, St. Paul, v. 74, n.9, p. 1081-1085, 1984. 